Abstracted/indexed in Academic Search Complete, Agroforestry Abstracts, Asia Journals Online, Bangladesh Journals Online, Biological Abstracts, BIOSIS Previews, CAB Abstracts, Current Abstracts, Directory of Open Access Journals, EMBASE/Excerpta Medica, Google Scholar, HINARI (WHO), International Pharmaceutical Abstracts, Open J-gate, Science Citation Index Expanded, SCOPUS and Social Sciences Citation Index; ISSN: 1991-0088

\title{
Synthesis and biological evaluation of new hydrazide-Schiff bases
}

\author{
Asif Husain', Munendra M. Varshney², Versha Parcha ${ }^{3}$, Aftab Ahmad4 and \\ Shah Alam Khans
}

${ }^{1}$ Department of Pharmaceutical Chemistry, Hamdard University, New Delhi 110 062, India; ${ }^{2}$ College of Pharmaceutical Sciences, Raj Kumar Goel Institute of Technology, Ghaziabad, U.P. 201003 , India; ${ }^{3}$ Sardar Bhagwan Singh Post Graduate Institute of Biomedical Sciences and Research, Dehradun, Uttarakhand, India; ${ }^{4}$ Health Information Technology Department, Jeddah Community College, King Abdul Aziz University, Jeddah 21 589, KSA; ${ }^{5}$ Dept of Pharmacy, Oman Medical College, PO Box 620, PC 130, Muscat, Sultanate of Oman.

\begin{tabular}{|lr|}
\hline Article Info \\
\hline Received: & 14 May 2015 \\
Accepted: & 19 June 2015 \\
Available Online: & 1 July 2015 \\
DOI: 10.3329/bjp.v10i3.23381 \\
\\
\\
Cite this article: \\
Husain A, Varshney MM, Parcha V, \\
Ahmad A, Khan SA. Synthesis and bio- \\
logical evaluation of new hydrazide- \\
Schiff bases. Bangladesh J Pharmacol. \\
2015; 10: 555-61.
\end{tabular}

\begin{abstract}
A new series of $\mathrm{N}-(\{5$-(substituted aryl)-furan-2-yl $\}$-methylidene)-hydrazides were synthesized with a new class of Schiff bases derived from the reaction of substituted phenyl-1-ketohydrazide 2 or 2-(4-chloro-3-methylaryloxy) acetohydrazide 3 with different 5-(substituted aryl)-2-furfuraldehyde (1a-k) to yield substituted $\mathrm{N}-(\{5-($ substituted aryl)-furan-2-yl\}-methylidene)-hydrazides -Schiff bases (4a-f, $\mathbf{4 g - k}$ ). The title compounds were subjected to in vitro antibacterial screening against Gram positive bacterial strains- S. aureus, $B$. cereus, E. faecalis and S. epidermidis, and Gram negative bacteria strains- E. coli, S. typhi, S.dysenteriae and K. pneumoniae. The synthesized Schiff bases were also evaluated for their anthelmintic activity against two species of earthworms (Pheretima posthuma and Perionyx excavatus). Some compounds have shown promising antibacterial and anthelmintic activities.
\end{abstract}

\section{Introduction}

Resistance to a number of antimicrobial agents by a variety of pathogenic bacteria is becoming a major global problem. The widespread use and misuse of antibiotics is one of the cause attributed to the emer-gence of drug resistance to majority of antibacterial agents (Mashrai et al., 2014). It warrants the scientific community to develop new antimicrobial agents with potent and broad spectrum of antimicrobial action against resistant pathogens vis a vis cheap and safe. Therefore, there is a wide scope on research on newer antibacterial agents. Another important public health problem is helminthiasis or worm infestations. It is a cause of several related diseases caused by a variety of worms and exists worldwide. Very few drugs are avai-lable in the market to treat all worm infestations. The situation is worsened due to unavailability of an ideal anthelmintic vaccine (Newton and Munn, 1999). Though research is going on but its delayed development has necessitated the discovery of new anthelmintic compounds that could be used effectively to circumvent the current situation.

Extensive literature survey shows that phenolic and haloaryl rings are associated with anthelmintic and anti -intestinal nematode (Duan et al., 2011), antioxidant (Valentina et al., 2009) and antibacterial activity (Husain et al., 2010). Schiff bases are important class of organic compounds with imine or azomethine $(-\mathrm{C}=\mathrm{N}-)$ functional group. These are prepared by condensing primary amines with carbonyl compounds (Dhar and Taploo, 1982). Schiff bases are reported to possess diverse biological and pharmacological actions including potential anti-inflammatory (Gurupadayya et al., 2008), antibacterial (Hearn et al., 2009), antitubercular (Aboul-Fadl et al., 2010) antiviral (Kumar et al., 2010.), anticonvulsant (Firke et al., 2009), and anthelmintic (Sharma et al., 2009) activities. It was proposed wide spectrum of biological activities of Schiff bases could be 
because of the interaction of nitrogen atom of azomethine with the active centers of cell constituents by forming a hydrogen bond and thus it interferes in normal cell processes (Venugopala and Jayashree, 2003).

Owing to the antimicrobial and anthelmintic activities of substituted furfuraldehyde, phenolic and haloaryl moiety, it was thought worthwhile to synthesize some new compounds comprising of these moieties as a part of their structures, with an objective to obtain potential antimicrobial and anthelmintic agents with enhanced biological activities. Therefore, several N-(\{5-(substituted aryl)-furan-2-yl\}-methylidene)-hydrazides (4a-f, 4gk) Schiff bases were synthesized via synthesis of substituted phenyl-1-ketohydrazide 2 and 2-(4-chloro-2methylaryloxy)-acetohydrazide 3 with different aromatic 5-(substituted aryl)-2-furfuraldehyde (1a-k). The novel Schiff bases were chemically characterized and screened for their antimicrobial and anthelmintic activities.

\section{Materials and Methods}

\section{Chemistry}

Melting points were determined in one end open capillary tubes and were uncorrected. Thin-layer chromatography was carried out to monitor the reactions using silica gel $G$ plates. The IR spectra were recorded on Bruker, alpha E ATR FTIR spectrophotometer. ${ }^{1} \mathrm{H}-\mathrm{NMR}$ spectra were recorded on Bruker spectrospin DPX-300 MHz in DMSO-d6; chemical shift (ठ) values are reported in parts per million $(p p m)$. The splitting pattern abbreviations are as follows: $s$, singlet; $d$, doublet; $t$, triplet; $m$, multiplet. Mass spectra were scanned on Brukers micrOTOF-QII, ESI mass spectro- photometer. Elemental analyses $(\mathrm{C}, \mathrm{H}$, and $\mathrm{N}$ ) were done on a $\mathrm{CHN}$ rapid analyzer and reported in percentage abundance within $\pm 0.04 \%$ of the theoretical values. Spectral and micro-analysis data are consistent with the assigned structures.

Ketohydrazides (2), and 5-(phenyl substituted)-2-furfuraldehydes (3) were prepared by reported method (Varshney et al., 2014).

General procedure for the synthesis of $N$-[\{5-(substituted aryl)-furan-2-yl\}-methylidene]-hydrazides $(4 \boldsymbol{a}-\boldsymbol{f}, \mathbf{4 g - k})$ Schiff bases: A mixture of ketohydrazide $2(0.1 \mathrm{~mol})$ and 5(phenyl substituted)-2-furfuraldehyde 3 (0.05 mol) was refluxed on water bath for 7-8 hours in ethanol as solvent and in the presence of few drops of sulfuric acid as catalyst. The progress of the reaction was monitored by TLC. After completion of reaction, the reaction mixture was allowed to cool; crystals formed were washed, dried and finally recrystallized with ethanol to furnish the desired compound ( $4 a-f, 4 g-k$; Table I).

2-(2-Hydroxyphenyl)-N-[\{5-(4-nitrophenyl)-furan-2-yl\}methylidene]-ketohydrazide (4a): IR ( $\left.\mathrm{v}_{\max }, \mathrm{cm}^{-1}\right): 1653$ (CO of CONH), 1619, 3331 (NH of CONH), 1552, 1456, 1218, 1192, 1069, 913, 729 (C=C and C-H of aromatic ring); ${ }^{1} \mathrm{H}$ NMR: (DMSO- $\left.d_{6}, \delta, \mathrm{ppm}\right): 4.51(1 \mathrm{H}, \mathrm{s}, \mathrm{OH}), 6.73-7.80$ $(10 \mathrm{H}, \mathrm{m}, \mathrm{Ar}), 9.48(1 \mathrm{H}, \mathrm{s}, \mathrm{N}=\mathrm{CH}), 9.87(1 \mathrm{H}, \mathrm{s}, \mathrm{CONH})$; EI-MS $(m / z, \%) ; 351[\mathrm{M}+1,100]$; Anal. Calcd. for $\mathrm{C}_{18} \mathrm{H}_{13} \mathrm{~N}_{3} \mathrm{O}_{5}$ : C, 61.54; H, 3.73, N, 11.75. Found: C, 61.49; $\mathrm{H}, 3.74, \mathrm{~N}, 11.76$.

2-(2-Hydroxyphenyl)-N-[5-(4-chlorophenyl)-furan-2-yl]methylidene]-ketohydrazide (4b): IR ( $\left.\mathrm{V}_{\max }, \mathrm{cm}^{-1}\right)$ : 1651 (CO of CONH), 1623, 3312 (NH of CONH), 1548, 1459, 1216, 1158, 1064, 986, 718 (C=C and C-H of aromatic ring); ${ }^{1} \mathrm{H}$ NMR: (DMSO- $\left.d_{6}, \delta, \mathrm{ppm}\right): 4.22(1 \mathrm{H}, \mathrm{s}, \mathrm{OH}), 6.82-7.69$ (10H, m, Ar), 9.93 (1H, s, CONH $), 10.12$ (1H, s, N=CH);

\begin{tabular}{|c|c|c|c|c|c|c|c|}
\hline \multicolumn{8}{|c|}{ Table I } \\
\hline \multicolumn{8}{|c|}{ Physical data of title compounds (4a-k) } \\
\hline Compd. & $\mathrm{R}_{1}$ & $\mathrm{R}$ & $\begin{array}{l}\text { Molecular } \\
\text { Formula }\end{array}$ & M.P $\left({ }^{\circ} \mathrm{C}\right)$ & M.Wt. & Physical state & $\%$ Yield \\
\hline $4 a$ & 4-Nitrophenyl & 2-Hydroxy & $\mathrm{C}_{18} \mathrm{H}_{13} \mathrm{~N}_{3} \mathrm{O}_{5}$ & $190-192$ & 351 & Pale brown crystals & 39 \\
\hline $4 b$ & 4-Chlorophenyl & 2-Hydroxy & $\mathrm{C}_{18} \mathrm{H}_{13} \mathrm{ClN}_{2} \mathrm{O}_{3}$ & 168 & 340 & Brown crystals & 23 \\
\hline $4 c$ & 4-Bromophenyl & 2-Hydroxy & $\mathrm{C}_{18} \mathrm{H}_{13} \mathrm{BrN}_{2} \mathrm{O}_{3}$ & $181-183$ & 385 & Brown crystals & 56 \\
\hline $4 d$ & 4-Methylphenyl & 2-Hydroxy & $\mathrm{C}_{19} \mathrm{H}_{16} \mathrm{~N}_{2} \mathrm{O}_{3}$ & 194-196 & 320 & Pale brown crystals & 77 \\
\hline $4 \mathrm{e}$ & 4-Methoxyphenyl & 2-Hydroxy & $\mathrm{C}_{19} \mathrm{H}_{16} \mathrm{~N}_{2} \mathrm{O}_{4}$ & 166 & 336 & Dark brown crystals & 73 \\
\hline $4 \mathrm{f}$ & 2,4-Dinitrophenyl & 2-Hydroxy & $\mathrm{C}_{18} \mathrm{H}_{12} \mathrm{~N}_{4} \mathrm{O}_{7}$ & $150-151$ & 396 & Dark brown crystals & 70 \\
\hline $4 \mathrm{~g}$ & 4-Sulfoxyphenyl & 2-Methyl & $\mathrm{C}_{20} \mathrm{H}_{17} \mathrm{C}_{2} \mathrm{O}_{6} \mathrm{~S}$ & $131-133$ & 413 & Pale Brown crystals & 54 \\
\hline $4 \mathrm{~h}$ & 2-carboxyphenyl & 2-methyl & $\mathrm{C}_{21} \mathrm{H}_{17} \mathrm{ClN}_{2} \mathrm{O}_{5}$ & 162 & 412 & Yellow crystals & 46 \\
\hline $4 \mathrm{i}$ & 3-chlorophenyl & 2-methyl & $\mathrm{C}_{20} \mathrm{H}_{16} \mathrm{Cl}_{2} \mathrm{~N}_{2} \mathrm{O}_{3}$ & $135-136$ & 402 & Dark brown crystals & 48 \\
\hline $4 j$ & 4-carboxyphenyl & 2-methyl & $\mathrm{C}_{21} \mathrm{H}_{17} \mathrm{ClN}_{2} \mathrm{O}_{5}$ & $128-130$ & 412 & Brown crystals & 51 \\
\hline $4 \mathrm{k}$ & 4-sulfacetamidophenyl & 2-methyl & $\mathrm{C}_{22} \mathrm{H}_{20} \mathrm{Cl}_{3} \mathrm{O}_{6} \mathrm{~S}$ & 176 & 489 & Brown crystals & 65 \\
\hline
\end{tabular}


EI-MS (m/z, \%): 340 [M+1, 100]; Anal. Calcd. for $\mathrm{C}_{18} \mathrm{H}_{13} \mathrm{ClN}_{2} \mathrm{O}_{3}$ : C, 63.54; $\mathrm{H}, 3.85, \mathrm{~N}, 10.40$. Found: $\mathrm{C}$, 63.58; H, 3.86, N, 10.44 .

2-(2-Hydroxyphenyl)-N-(\{5-(4-bromophenyl)-furan-2-yl\}methylidene]-ketohydrazide (4c): IR ( $\left.\mathrm{v}_{\max }, \mathrm{cm}^{-1}\right)$ : $1644(\mathrm{CO}$ of $\mathrm{CONH}), 1604,3328$ (NH of $\mathrm{CONH}), 1546,1449,1228$, 1151, 1022, 931, 737 (C=C and C-H of aromatic ring); ${ }^{1} \mathrm{H}$ NMR: (DMSO- $\left.d_{6}, \delta, \mathrm{ppm}\right): 4.04(1 \mathrm{H}, \mathrm{s}, \mathrm{OH}), 6.73-7.82$ $(10 \mathrm{H}, \mathrm{m}, \mathrm{Ar}), 9.69(1 \mathrm{H}, \mathrm{s}, \mathrm{N}=\mathrm{CH}), 9.77(1 \mathrm{H}, \mathrm{s}, \mathrm{CONH})$; EI-MS $(m / z, \%)$ : 385 [M+1, 100]; Anal. Calcd. for $\mathrm{C}_{18} \mathrm{H}_{13} \mathrm{BrN}_{2} \mathrm{O}_{3}$ : C, 56.12; H, 3.40, N, 7.27. Found: C, 55.96; H, 3.43, N, 7.25.

2-(2-Hydroxyphenyl)-N-[\{5-(4-methylphenyl)-furan-2-yl\}methylidene]-ketohydrazide (4d): IR $\left(\mathrm{v}_{\max }, \mathrm{cm}^{-1}\right)$ : 1635 (CO of CONH), 1633, 3342 (NH of CONH), 1542, 1458, 1237, 1164, 1075, 956, 749 (C=C and $\mathrm{C}-\mathrm{H}$ of aromatic ring); ${ }^{1} \mathrm{H}$ NMR: (DMSO- $\left.d_{6}, \delta, \mathrm{ppm}\right): 3.16\left(3 \mathrm{H}, \mathrm{s}, \mathrm{CH}_{3}\right), 4.33(1 \mathrm{H}, \mathrm{s}$, $\mathrm{OH})$, 6.57-7.82 (10H, m, Ar), $9.59(1 \mathrm{H}, \mathrm{s}, \mathrm{N}=\mathrm{CH}), 9.90$ (1H, s, CONH); EI-MS (m/z, \%): $320(\mathrm{M}+1,100)$; Anal. Calcd. for $\mathrm{C}_{19} \mathrm{H}_{16} \mathrm{~N}_{2} \mathrm{O}_{3}: \mathrm{C}, 71.24 ; \mathrm{H}, 5.03, \mathrm{~N}, 8.04$. Found: C, 71.25; H, 5.05, N, 8.07.

2-(2-Hydroxyphenyl)-N-[\{5-(4-methoxyphenyl)-furan-2-yl\}methylidene]-ketohydrazide (4e): IR ( $\left.\mathrm{v}_{\max }, \mathrm{cm}^{-1}\right)$ : 1648 (CO of $\mathrm{CONH}), 1609,3316$ (NH of CONH), 1282 (C-O-C of $\left.\mathrm{Ar}-\mathrm{OCH}_{3}\right), 1540,1424,1227,1167,1054,940,745$ (C=C and $\mathrm{C}-\mathrm{H}$ of aromatic ring); ${ }^{1} \mathrm{H}$ NMR: (DMSO- $d_{6}, \delta$, ppm): 4.23 (1H, s, OH), 6.87-7.79 (10H, m, Ar), $9.94(1 \mathrm{H}$, $\mathrm{s}, \mathrm{N}=\mathrm{CH}), 10.24(1 \mathrm{H}, \mathrm{s}, \mathrm{CONH}) ; \operatorname{EI}-\mathrm{MS}(\mathrm{m} / \mathrm{z}, \%): 336$ $(\mathrm{M}+1,100)$; Anal. Calcd. for $\mathrm{C}_{19} \mathrm{H}_{16} \mathrm{~N}_{2} \mathrm{O}_{4}$ : C, 67.85; $\mathrm{H}$, 4.79, N, 8.33. Found: C, 67.82; H, 4.74, N, 8.29.

2-(2-Hydroxyphenyl)-N-[\{5-(2,4-dinitrophenyl)-furan-2-yl\}methylidene]-ketohydrazide (4f): IR ( $\left.\mathrm{v}_{\max }, \mathrm{cm}^{-1}\right)$ : 1660 (CO of CONH), 1541, 3389 (NH of CONH), 1515, 1457, 1236, 1108, 1067, 992, 746 (C=C and C-H of aromatic ring); ${ }^{1} \mathrm{H}$ NMR: (DMSO- $\left.d_{6}, \delta, \mathrm{ppm}\right): 3.98(1 \mathrm{H}, \mathrm{s}, \mathrm{OH}), 6.91-8.89$ $(9 \mathrm{H}, \mathrm{m}, \mathrm{Ar}), 9.86(1 \mathrm{H}, \mathrm{s}, \mathrm{N}=\mathrm{CH}), 9.95(1 \mathrm{H}, \mathrm{s}, \mathrm{CONH})$; EIMS $(\mathrm{m} / z, \%)$ : $396[\mathrm{M}+1,100]$; Anal. Calcd. for $\mathrm{C}_{18} \mathrm{H}_{12} \mathrm{~N}_{4} \mathrm{O}_{7}$ : C, 54.55; H, 3.05, N, 14.14. Found: C, 54.24; $\mathrm{H}, 3.09, \mathrm{~N}, 13.90$.

2-(4-Chloro-2-methylphenoxy)-N-[\{5-(4-sulfoxyphenyl)furan-2-yl\}-methylidene]-acetohydrazide $(\mathbf{4 g})$ : IR ( $\mathrm{v}_{\max }, \mathrm{cm}^{-}$ 1): 1173 (C-O-C), 1672 (CO of CONH), 1626, 3353 (NH of $\mathrm{CONH}), 1547,1464,1265,1169,1102,941,742(\mathrm{C}=\mathrm{C}$ and $\mathrm{C}-\mathrm{H}$ of aromatic ring); ${ }^{1} \mathrm{H}$ NMR: (DMSO- $\left.d_{6}, \delta, \mathrm{ppm}\right)$ : $2.24\left(3 \mathrm{H}, \mathrm{s}, \mathrm{CH}_{3}\right), 4.61\left(2 \mathrm{H}, \mathrm{s}, \mathrm{OCH}_{2}\right), 6.72-8.38(9 \mathrm{H}, \mathrm{m}$, Ar-H), 9.42 (1H, s, N=CH), $10.18(1 \mathrm{H}, \mathrm{s}, \mathrm{CONH})$; EI-MS $(\mathrm{m} / \mathrm{z}, \%): 449$ [M+1, 100]; Anal. Calcd. for $\mathrm{C}_{20} \mathrm{H}_{17} \mathrm{ClN}_{2} \mathrm{O}_{6} \mathrm{~S}: \mathrm{C}, 53.51 ; \mathrm{H}, 3.82, \mathrm{~N}$, 6.24. Found: C, 53.54; H, 3.85, N, 6.27.

2-(4-Chloro-2-methylphenoxy)-N-[\{5-(2-carboxyphenyl)furan-2-yl\}-methylidene]-acetohydrazide $(4 \mathrm{~h})$ : IR ( $\mathrm{v}_{\max }, \mathrm{cm}^{-}$ 1): 1167 (C-O-C), 1678 (CO of CONH), 1648, $3324(\mathrm{NH}$ of $\mathrm{CONH}), 1543,1424,1209,1162,1098,875,807,775$ $\left(\mathrm{C}=\mathrm{C}\right.$ and $\mathrm{C}-\mathrm{H}$ of aromatic ring); ${ }^{1} \mathrm{H}$ NMR: (DMSO- $d_{6}, \delta$, ppm): 2.29 ( $\left.3 \mathrm{H}, \mathrm{s}, \mathrm{CH}_{3}\right), 4.65\left(2 \mathrm{H}, \mathrm{s}, \mathrm{OCH}_{2}\right), 6.59-8.06$
(9H, m, Ar-H), 9.54 (1H, s, N=CH), 10.16 (1H, s, $\mathrm{CONH})$; EI-MS (m/z, \%): 413 [M+1, 100]; Anal. Calcd. for $\mathrm{C}_{21} \mathrm{H}_{17} \mathrm{ClN}_{2} \mathrm{O}_{5}$ : C, 61.01; $\mathrm{H}, 4.15, \mathrm{~N}, 6.79$. Found: $\mathrm{C}$, 61.35; H, 3.87, N, 6.82 .

2-(4-Chloro-2-methylphenoxy)-N-[\{5-(3-chlorophenyl)-furan -2-yl\}-methylidene]-acetohydrazide (4i): IR $\left(\mathrm{v}_{\max }, \mathrm{cm}^{-1}\right)$ : 1175 (C-O-C), 1678 (CO of CONH), 1625, 3326 (NH of $\mathrm{CONH}), 1547,1461,1262,1161,1117,865,730$ (C=C and $\mathrm{C}-\mathrm{H}$ of aromatic ring); ${ }^{1} \mathrm{H}$ NMR: (DMSO- $\left.d_{6}, \delta, \mathrm{ppm}\right)$ : $2.27\left(3 \mathrm{H}, \mathrm{s}, \mathrm{CH}_{3}\right), 4.67\left(2 \mathrm{H}, \mathrm{s}, \mathrm{OCH}_{2}\right), 6.67-8.48(9 \mathrm{H}, \mathrm{m}$, Ar-H), 9.57 (1H, s, N=CH), $10.13(1 \mathrm{H}, \mathrm{s}, \mathrm{CONH})$; EI-MS $(\mathrm{m} / \mathrm{z}, \%): 404 \quad[\mathrm{M}+1,100]$; Anal. Calcd. for $\mathrm{C}_{20} \mathrm{H}_{16} \mathrm{Cl}_{2} \mathrm{~N}_{2} \mathrm{O}_{3}$ : C, 59.57; $\mathrm{H}, 4.00, \mathrm{~N}$, 6.95. Found: C, $59.63 ; \mathrm{H}, 4.05, \mathrm{~N}, 6.96$.

2-(4-Chloro-2-methylphenoxy)-N-[\{5-(4-carboxyphenyl)furan-2-yl\}-methylidene]-acetohydrazide $(4 \mathrm{j})$ : IR ( $\mathrm{v}_{\max }, \mathrm{cm}^{-}$ 1): 1150 (C-O-C), 1675 (CO of CONH), 1623, $3324(\mathrm{NH}$ of $\mathrm{CONH}), 1542,1462,1264,1167,1121,858,720$ (C=C and $\mathrm{C}-\mathrm{H}$ of aromatic ring); ${ }^{1} \mathrm{H}$ NMR: (DMSO- $d_{6}, \delta$, ppm): 2.29 ( $\left.3 \mathrm{H}, \mathrm{s}, \mathrm{CH}_{3}\right), 4.61\left(2 \mathrm{H}, \mathrm{s}, \mathrm{OCH}_{2}\right), 6.65-7.95$ $(9 \mathrm{H}, \mathrm{m}, \mathrm{Ar}-\mathrm{H}), 9.36(1 \mathrm{H}, \mathrm{s}, \mathrm{N}=\mathrm{CH}), 10.19$ (1H, s, $\mathrm{CONH})$; $\operatorname{EI-MS}(\mathrm{m} / \mathrm{z}, \%): 413[\mathrm{M}+1,100]$; Anal. Calcd. for $\mathrm{C}_{21} \mathrm{H}_{17} \mathrm{ClN}_{2} \mathrm{O}_{5}$ : C, 61.01; $\mathrm{H}, 4.15, \mathrm{~N}, 6.79$. Found: $\mathrm{C}$, 61.28; H, 3.77, N, 6.82 .

2-(4-Chloro-2-methylphenoxy)-N-[\{5-(4-sulfacetamidophenyl)-furan-2-yl\}-methylidene]-acetohydrazide (4k): IR ( $\left.v_{\max }, \mathrm{cm}-1\right)$ : 1158 (C-O-C), 1674 (CO of CONH), 1620, $3344(\mathrm{NH}$ of $\mathrm{CONH}), 1171\left(\mathrm{SO}_{2}\right.$ of $\left.\mathrm{SO}_{2} \mathrm{NH}\right), 1541,1462$, $1264,1170,1117,852,711$ (C=C and C-H of aromatic ring); ${ }^{1} \mathrm{H}$ NMR: (DMSO- $\left.d_{6}, \delta, \mathrm{ppm}\right): 2.31\left(3 \mathrm{H}, \mathrm{s}, \mathrm{CH}_{3}\right)$, $4.67\left(2 \mathrm{H}, \mathrm{s}, \mathrm{OCH}_{2}\right), 6.71-7.95(9 \mathrm{H}, \mathrm{m}, \mathrm{Ar}-\mathrm{H}), 8.16(1 \mathrm{H}, \mathrm{s}$, $\left.\mathrm{SO}_{2} \mathrm{NH}\right), 9.32(1 \mathrm{H}, \mathrm{s}, \mathrm{N}=\mathrm{CH}), 10.21(1 \mathrm{H}, \mathrm{s}, \mathrm{CONH}) ; \mathrm{EI}-$ MS (m/z, \%): 490 [M+1, 100]; Anal. Calcd. for $\mathrm{C}_{22} \mathrm{H}_{20} \mathrm{ClN}_{3} \mathrm{O}_{6} \mathrm{~S}$ : C, 52.23; H, 3.98, N, 8.31. Found: C, $52.05 ; \mathrm{H}, 4.02, \mathrm{~N}, 8.12$.

\section{Biological evaluation}

The title compounds were evaluated for their antibacterial and anthelmintic activities.

\section{Antibacterial activity}

Antibacterial activity of the newly synthesized Schiff bases was evaluated by disc diffusion method (Cruickshank et al., 1975; Elmer et al., 2002) against four gram positive bacterial strains; S. aureus, B. cereus, E. faecalis, $S$. epidermidis, and four gram negative bacterial strains; E. coli, S. typhi, S. dysenteriae and K. pneumoniae taking ampicillin (20 $\mu \mathrm{g} /$ disc $)$ as reference drug. Standard inoculums ( $1 \mathrm{~mL} / 100 \mathrm{~mL}$ of medium) with suspension were introduced onto the surface of sterile agar plates, and a sterile bent glass spreader was used for even distribution of the inoculums. The discs measuring $6 \mathrm{~mm}$ in diameter were prepared from Whatman (Grade No. 1) filter paper and sterilized by dry heat for 1 hour. Three discs of test samples were placed on three portion together with one disc having the reference 
drug (ampicillin), and one disc impregnated with solvent (DMF) as negative control. The sterile discs previously soaked in a known concentration $(25 \mu \mathrm{g} / \mathrm{mL}$ in dimethyl formamide) of the test compounds were placed in nutrient agar medium. Plates were inverted and incubated for 24 hours at $37 \pm 1^{\circ} \mathrm{C}$. Diameters of zone of inhibition $(\mathrm{mm})$ were determined and average diameter of test samples were calculated in triplicate sets. Zone of inhibition of test compounds were compared with that of the standard.

\section{Anthelmintic activity}

Anthelmintic activity was carried out against two different species of worms; Pheretima posthuma and Perionyx excavatus, at a $2 \mathrm{mg} / \mathrm{mL}$ concentration (Dahiya and Pathak 2007). Collected earthworms were washed with normal saline water to remove soil and fecal matter. Suspensions of samples were prepared by triturating synthesized compounds (100 $\mathrm{mg}$ ) with Tween 80 $(0.5 \%)$ and normal saline solution and the resulting mixtures were stirred for $30 \mathrm{~min}$. The suspensions were diluted to obtain conc. of $0.2 \% \mathrm{w} / \mathrm{v}$ of the test samples. Suspension of reference drug albendazole $(0.2 \% \mathrm{w} / \mathrm{v})$ was prepared with the same manner. Three sets of five earthworms of almost similar sizes (approx. 2 inch in length) were placed in petri plates of 4 inch diameter containing $50 \mathrm{~mL}$ of suspension of test samples and reference drug. Another set of five earthworms was kept as control in $50 \mathrm{~mL}$ suspension of distilled water and tween $80(0.5 \%)$. The paralyzing and death times were noted and their mean was calculated for triplicate sets.

\section{Statistical analysis}

The statistics i.e. one way ANOVA and $t$-test were applied on the values of mean \pm SEM of triplicates $(n=3)$ zone of growth of inhibition of test compounds, and compared with standard drug ampicillin with control as DMF (dimethyl formamide). While data of anthelmintic activity of the test compounds was analyzed by mean $\pm S D(n=5)$ and compared with albendazole.

\section{Results and Discussion}

\section{Chemistry}

The primary aim of this study was to condense a biologically active pharmacophore such as furan with an acid hydrazide to obtain Schiff bases as source of potential antimicrobial and anthelminitic agents. The five membered oxygen containing heterocyclic nucleus was also substituted at $5^{\text {th }}$ position to study the effect of various substituents on biological activity. It has been reported that hyrazide Schiff bases prepared from aromatic hydroxy aldehydes found significant applications in analytical and pharmaceutical industries (Nath et al., 2001; Tarafdar and Khan, 1991). Schiff bases have been of great importance due to their synthetic flexibility, selectivity and sensitivity towards the metal ions. Heterocyclic ring containing oxygen atom further imparts broad spectrum of biological activity to Schiff's bases (Nair et al., 1983).

The title compounds, N-[\{5-(substituted aryl)-furan-2yl\}-methylidene]-hydrazides (4a-f, 4g-k) Schiff bases were synthesized by condensing ketohydrazide 2 with 5-(phenyl substituted)-2-furfuraldehyde 3 in presence of sulfuric acid (Scheme 1). The compounds were characterized by IR, ${ }^{1} \mathrm{H}-\mathrm{NMR}$, Mass spectral data and elemental ( $\mathrm{C}, \mathrm{H}, \mathrm{N})$ analysis. The compounds were obtained in moderate to good yield. The IR spectra of

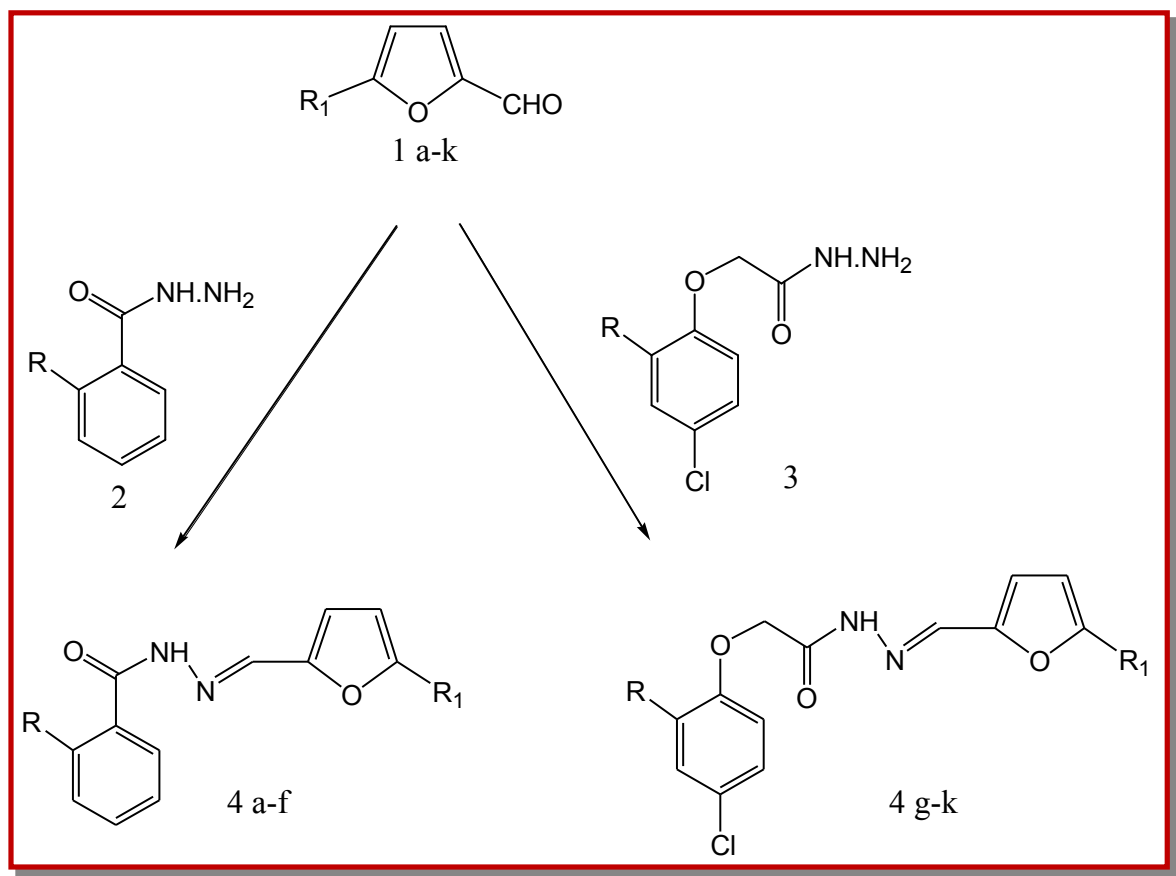

Scheme 1: Protocol for the synthesis of hydrazide-Schiff bases 


\begin{tabular}{|c|c|c|c|c|c|c|c|c|}
\hline \multicolumn{9}{|c|}{ Table II } \\
\hline \multicolumn{9}{|c|}{ Antibacterial activity of title compounds (4a-k) } \\
\hline \multirow[t]{3}{*}{ Compd. } & \multicolumn{8}{|c|}{ Antibacterial activity (Zone of inhibition in $\mathrm{mm}$ ) } \\
\hline & \multicolumn{4}{|c|}{ Gram $(+)$ bacteria } & \multicolumn{4}{|c|}{ Gram (-) bacteria } \\
\hline & SA & $\mathrm{BC}$ & $\mathrm{EF}$ & SE & EC & ST & SD & $\mathrm{KP}$ \\
\hline $4 a$ & $10 \pm 0.5$ & $12 \pm 0.4$ & $21 \pm 0.7$ & $12 \pm 0.7$ & $8 \pm 0.6$ & $16 \pm 0.8$ & $19 \pm 0.2$ & $17 \pm 0.2$ \\
\hline $4 \mathrm{~b}$ & $8 \pm 0.3$ & $12 \pm 0.6$ & $13 \pm 0.2$ & $7 \pm 0.2$ & $7 \pm 0.3$ & $10 \pm 0.4$ & $8 \pm 0.2$ & $10 \pm 0.4$ \\
\hline $4 \mathrm{c}$ & $11 \pm 0.1$ & $15 \pm 0.3$ & $16 \pm 0.3$ & $19 \pm 0.6$ & $18 \pm 0.2$ & $21 \pm 0.7$ & $23 \pm 0.3$ & $12 \pm 0.3$ \\
\hline $4 d$ & $7 \pm 0.3$ & $21 \pm 0.5$ & $20 \pm 0.5$ & $8 \pm 0.4$ & $11 \pm 0.4$ & $11 \pm 0.3$ & $13 \pm 0.4$ & $22 \pm 0.4$ \\
\hline $4 e$ & $18 \pm 0.2$ & $11 \pm 0.3$ & $16 \pm 0.1$ & $13 \pm 0.6$ & $7 \pm 0.5$ & $13 \pm 0.8$ & $9 \pm 0.2$ & $15 \pm 0.3$ \\
\hline $4 \mathrm{f}$ & $17 \pm 0.3$ & $15 \pm 0.1$ & $18 \pm 0.9$ & $20 \pm 0.2$ & $9 \pm 0.6$ & $17 \pm 0.3$ & $23 \pm 0.4$ & $20 \pm 0.7$ \\
\hline $4 \mathrm{~g}$ & $8 \pm 0.3$ & $21 \pm 0.5$ & $23 \pm 0.0$ & $14 \pm 0.5$ & $18 \pm 0.0$ & $11 \pm 0.7$ & $17 \pm 0.7$ & $24 \pm 0.4$ \\
\hline $4 \mathrm{~h}$ & $9 \pm 0.1$ & $16 \pm 0.0$ & $14 \pm 0.0$ & $16 \pm 0.1$ & $9 \pm 0.3$ & $13 \pm 0.0$ & $15 \pm 0.0$ & $21 \pm 0.0$ \\
\hline $4 \mathrm{i}$ & $12 \pm 0.4$ & $21 \pm 0.0$ & $11 \pm 0.0$ & $14 \pm 0.0$ & $16 \pm 0.0$ & $17 \pm 0.3$ & $19 \pm 0.0$ & $13 \pm 0.0$ \\
\hline $4 j$ & $14 \pm 0.0$ & $24 \pm 0.0$ & $13 \pm 0.1$ & $16 \pm 02$ & $18 \pm 0.0$ & $21 \pm 0.0$ & $22 \pm 0.5$ & $12 \pm 0.3$ \\
\hline $4 \mathrm{k}$ & $24 \pm 0.2$ & $12 \pm 0.4$ & $22 \pm 0.3$ & $25 \pm 0.5$ & $17 \pm 0.3$ & $22 \pm 0.5$ & $22 \pm 0.3$ & $26 \pm 0.2$ \\
\hline Ampicillin & $25 \pm 0.0$ & $25 \pm 0.0$ & $26 \pm 0.0$ & $24 \pm 0.0$ & $22 \pm 0.0$ & $27 \pm 0.0$ & $26 \pm 0.0$ & $26 \pm 0.0$ \\
\hline
\end{tabular}

All the values are expressed as mean \pm SEM of triplicates; SA = Staphylococcus aureus $($ ATCC 11633); ST = Salmonella typhi (MTCC 733); SE = Staphylococcus epidermidis (ATCC 155); SD = Shigella dysenteriae (ATCC 13313); EC = Escherichia coli (ATCC10536); BC = Bacillus cereus (ATCC 11778); $\mathrm{EF}=$ Enterococccus faecalis (ATCC 14506); KP = Klebsiella pneumoniae (ATCC 10031); PA=Pseudomonas aeruginosa (ATCC 27853)

compounds (4a-f, 4g-k) showed absorption bands for $\mathrm{C}=\mathrm{O}$ of $\mathrm{CONH}$ at $1639-1698$; $\mathrm{NH}$ of $\mathrm{CONH}$ at $1607-1648$ and at 3312-3369 $\mathrm{cm}^{-1}$. The ${ }^{1} \mathrm{H}-\mathrm{NMR}$ spectra of title compounds showed the typical protons signals for $\mathrm{N}=\mathrm{CH}$ and $\mathrm{CONH}$ groups at $\delta$ 9.37-10.14 and 9.93-10.24 ppm range, respectively. The molecular ion peak $\left(\mathrm{M}^{+}\right)$ for all the synthesized compounds was also obtained in mass spectra and was of good intensity.

\section{Biological evaluation}

\section{Antibacterial activity}

In vitro antibacterial activity of the title compounds (4af, $\mathbf{4 g - k}$ ) was carried out against eight human pathogenic bacteria, four Gram positive bacterial strains; S.aureus, $B$. cereus, E. faecalis and S. epidermidis, and four Gram negative bacterial strains; E. coli, S. typhi, S. dysenteriae and K. pneumonia, respectively. The zone of inhibition of positive control ampicillin, against Gram positive bacteria was 22-26 $\mathrm{mm}$ and against Gram negative bacteria was in range of $22-27 \mathrm{~mm}$. The least sensitive Gram positive and negative bacteria against ampicillin were S. epidermidis and E. coli, while E. faecalis and $S$. typhi were most sensitive. All the tested compounds (4a -f, $\mathbf{4 g - k )}$ showed good antibacterial activity against all the tested strains. An analysis of results showed that, among tested compounds, the compounds $4 \mathrm{c}, \mathbf{4 f}, \mathbf{4 g}, \mathbf{4 i}$, $4 \mathbf{j}$ and $\mathbf{4 k}$ which have electron withdrawing groups (4bromo, 2,4-dinitro, 4-sulfoxy, 3-chloro, 4-carboxylic, and 4-sulfacetamido) on the phenyl ring, showed excellent antibacterial activity and found to be equipotent against $B$. cereus, $S$. dysenteriae, $S$. aureus, $S$. epidermidis and $K$. pneumoniae when compared with standard drug. Compounds $\mathbf{4 a}, \mathbf{4 b}, \mathbf{4 d}$ and $\mathbf{4 h}$ showed moderate antibacterial activity against $S$. aureus, $B$. cereus, E. faecalis, and S. epidermidis, E. coli, S. typhi, S. dysenteriae and K. pneumonia (Table II). It was interesting to note that compound $\mathbf{4 k}$ showed better zone of inhibition $(25 \mathrm{~mm})$ than the standard drug $(24 \mathrm{~mm})$ against $S$. epidermidis and also matched the standard (26 $\mathrm{mm}$ ) in antibacterial action against K. pneumoniae. Like our compounds, Schiff bases derived from isatin derivatives and $\mathrm{N}\left[4-\left(4^{\prime}\right.\right.$ chlorophenyl)thiozole-2-yl] thiosemicarbazide, have also shown to be potent antimicrobial agents (Pandeya et al., 1999). The antibacterial activity of N-(1-phenyl-2-hydroxy-2-phenylethylidine)$2^{\prime}, 4^{\prime}$ dinitrophenyl hydrazine was found to be at par with kanamycin at the same dose against $S$. aureus, $B$. megaterium, E. coli, S. dysenteriae, S. sonnei and $P$. aeruginosa (Jesmin et al., 2008). However, Siddique et al., in 2013 evaluated the antimicrobial activity of Schiff bases prepared from 4-chloro benzaldehyde and substituted hydrazides and reported them to be moderately active against Typhimusium Salmonella, Candida albicans, E. coli, B. subtilis while found to be inactive against $S$. aureus (Siddique et al., 2013).

\section{Anthelmintic activity}

The helminthes are the common cause of parasitic diseases in poverty stricken and developing countries with warm, moist environments with poor sanitary conditions (Sarnaim et al., 2013). Anthelmintic agents get rid of the parasitic worms by expelling them from the host body but the extensive use of these drugs have led to the development of resistance which necessitates the design and synthesis of potent and safe anthelmintic agents. Indian earthworms, $P$. posthuma and $P$. excavatus, due to their anatomical and 


\begin{tabular}{|c|c|c|c|c|}
\hline \multicolumn{5}{|c|}{ Table III } \\
\hline \multicolumn{5}{|c|}{ Anthelmintic activity of title compounds } \\
\hline & \multicolumn{2}{|c|}{ Perionyx excavatus } & \multicolumn{2}{|c|}{ Pheretima posthum } \\
\hline & $\begin{array}{l}\text { Mean paralyzing } \\
\text { time (min)a }\end{array}$ & $\begin{array}{l}\text { Mean death } \\
\text { time (min) }\end{array}$ & $\begin{array}{l}\text { Mean paralyzing time } \\
(\min )^{\mathrm{a}}\end{array}$ & $\begin{array}{l}\text { Mean death } \\
\text { time (min)a }\end{array}$ \\
\hline $4 a$ & $11.2 \pm 0.8$ & $15.5 \pm 0.8$ & $15.3 \pm 0.2$ & $22.3 \pm 0.4$ \\
\hline $4 b$ & $11.5 \pm 0.7$ & $17.4 \pm 0.7$ & $11.6 \pm 0.3$ & $16.3 \pm 0.9$ \\
\hline $4 \mathrm{c}$ & $12.2 \pm 0.3$ & $21.2 \pm 0.1$ & $15.4 \pm 0.3$ & $23.6 \pm 0.2$ \\
\hline $4 \mathrm{~d}$ & $13.7 \pm 0.7$ & $24.5 \pm 0.3$ & $14.8 \pm 0.6$ & $25.2 \pm 0.6$ \\
\hline $4 \mathrm{e}$ & $11.1 \pm 0.1$ & $21.4 \pm 0.4$ & $15.2 \pm 0.4$ & $28.2 \pm 0.2$ \\
\hline $4 f$ & $9.1 \pm 0.1$ & $23.4 \pm 0.4$ & $13.2 \pm 0.4$ & $22.2 \pm 0.2$ \\
\hline $4 \mathrm{~g}$ & $11.6 \pm 0.6$ & $24.3 \pm 0.2$ & $20.6 \pm 0.4$ & $26.5 \pm 0.1$ \\
\hline $4 h$ & $20.4 \pm 0.7$ & $22.6 \pm 0.5$ & $20.2 \pm 0.8$ & $24.5 \pm 0.7$ \\
\hline $4 \mathrm{i}$ & $11.3 \pm 0.8$ & $18.8 \pm 0.6$ & $13.4 \pm 0.4$ & $18.6 \pm 0.9$ \\
\hline $4 j$ & $14.5 \pm 0.7$ & $20.5 \pm 0.7$ & $19.4 \pm 0.3$ & $22.9 \pm 0.5$ \\
\hline $4 \mathrm{k}$ & $11.9 \pm 0.3$ & $17.7 \pm 0.4$ & $12.6 \pm 0.4$ & $20.8 \pm 0.7$ \\
\hline Albendazole & $10.1 \pm 0.7$ & $15.7 \pm 0.5$ & $11.5 \pm 0.9$ & $17.9 \pm 0.6$ \\
\hline Control & - & - & - & - \\
\hline
\end{tabular}

physiological resemblance to the intestinal roundworm parasites in humans were used for the evaluation of anthelminitic activity of the synthesized compounds.

The newly synthesized Schiff bases showed moderate to good anthelmintic activity at $2 \mathrm{mg} / \mathrm{mL}$ concentration. The results revealed that all the tested compounds were found to be effective against $P$. posthuma and $P$. excavatus, possessing significant activity in respect of mean paralyzing and mean death time. The mean paralyzing time ( $\mathrm{min}$ ) of tested compounds against $P$. excavatus and $P$. posthuma, was obser-ved to be 9.1020.35 and 11.6-20.6 min in comparison to 10.1 and 11.5 min shown by albendazole (Table III). The most and the least potent anthelmintic compound in terms of mean paralyzing time against $P$. excavatus was noted to be $\mathbf{4 f}$ (9.1 $\mathrm{min})$ and $4 \mathrm{~h}(20.4 \mathrm{~min})$, while against $P$. posthuma, $\mathbf{4 b}$ and $\mathbf{4 g}$ had the similar spectrum of activity. The Results were comparable to that of the standard drug. The mean death time observed for albendazole against P. posthuma and P. excavatus was 17.9 and $15.7 \mathrm{~min}$. Compounds $\mathbf{4 a}$ and $\mathbf{4 b}$ were found to be more potent than standard drug in causing death of nematodes, which took an average time of 15.5 and 16.3 min against P. excavatus and P. posthuma, respectively. Various condensed products of hydrazino benzthiazoles and isatin also showed the better activity than standard drug albendazole (Suresh et al., 2011). The possible mechanism of anthelmintic activity of these compounds could be due to their ability to provide two potential donor sites viz. oxygen and nitrogen atoms of ketohydrazide Schiff bases, which help in formation of hydrogen bond (s) (Venugopala and Jayashree, 2003) and thus might lead to the paralysis/death of parasitic worms.
The following is the proposed structure activity relationship (SAR) of the synthesized compounds: a) It was observed that substitution of aryl ring present at C5 position of furfuryl ring exhibits significant antibacterial and anthelmintic activities; b) introduction of substituted aryl ring in the Schiff bases enhances antimicrobial and anthelmintic actions; c) presence of electron withdrawing groups leads to improved and broad spectrum of biological activity.

\section{Conclusion}

To sum up, the newly synthesized hydrazide Schiff bases were successfully synthesized and evaluated for their antibacterial and anthelmintic activities with significant results. The study demonstrates the antibacterial and anthelmintic potential of hydrazide Schiff bases.

\section{Acknowledgement}

The authors are thankful to IIT-Delhi and Jamia Hamdard, New Delhi for spectral measurement. Thanks are also due to College of Pharmaceutical Sciences, RKGIT, Ghaziabad (U.P) for providing facilities.

\section{References}

Aboul-Fadl T, Bin-Jubair FAS, Aboul-Wafa, O. Schiff bases of indoline-2,3-dione (isatin) derivatives and nalidixic acid carbohydrazide, synthesis, antitubercular activity and pharmacophoric model building. Eur J Med Chem. 2010; 45: 457886. 
Cruickshank R, Duguid JP, Marion BP, Swain RHA. Medicinal microbiology. Vol. 2. $12^{\text {th }}$ ed. London, Churchill Livingstone, 1975, pp 196-202.

Dahiya R, Pathak D. Synthetic studies on novel benzimidazolopeptides with antimicrobial, cytotoxic and anthelmintic potential. Eur J Med Chem. 2007; 42: 772-98.

Dhar DN, Taploo CL. Schiff bases and their applications. J Sci Ind Res. 1982; 41: 501-06.

Duan LP, Wen AD, Wu NB, Tao Y, Zhang HB. Synthesis and anti-intestinal nematode activity of variously substituted benzonaphthyridine derivatives. Molecules 2011; 16: 1593602.

Elmer WK, Stephen DA, William MJ, Paul CS, Washing CW. Textbook of diagnostic microbiology. 5th ed. Lippincot Publishers, 2002.

Firke SD, Firake BM, Chaudhari RY, Patil VR . Synthetic and pharmacological evaluation of some pyridine containing thiazolidinones. Asian J Res Chem. 2009; 2: 157-61.

Gurupadayya BM, Gopal M, Padamshali, Manohara YN. Synthesis and pharmaceutical evaluation of azetidine-2-ones and thiazolidine-4-ones encompassing benzothiazole. Indian J Pharm Sci. 2008; 70: 572-77.

Hearn MJ, Cynamon MH, Chen MF, Coppins R. Preparation and antitubercular activities in vitro and in vivo of novel Schiff bases of isoniazid. Eur J Med Chem. 2009; 44: 4169-78.

Husain A. Ahmad A, Mujeeb, M, Akhter M. New amides of sulphonamides: Synthesis and biological evaluation. J Chil Chem Soc. 2010; 55: 74-77.

Jesmin M, Ali MM, Habib MR, Khanam JA. Antimicrobial activity of some Schiff bases derived from benzoin, salicylaldehyde, aminophenol and 2,4 dinitrophenyl hydrazine. Mycobiology 2008; 36: 70-73.

Kumar KS, Ganguly S, Veerasamy R, De Clercq E. Synthesis, antiviral activity and cytotoxicity evaluation of Schiff bases of some 2-phenyl quinazoline-4(3)H-ones. Eur J Med Chem. 2010; 45: 5474-79.

Mashrai A, Ahmad A, Dar AM, Khanam H, Danishuddin M, Khan AU. Synthesis, evaluation and docking studies on steroidal pyrazolones as anticancer and antimicrobial agents. Med Chem Res. 2014; 23: 348-62.

Nair UB, Ramasami T, Ramaswami D. Metal template synthesis of chromium (III) complexes. Polyhedron 1983; 2: 103-04.

Nath M, Pokharia S, Yadav R. Organotin (IV) complexes of amino acids and peptides. Coord Chem Rev. 2001; 215: 99149.

Newton SE, Munn EA. The development of vaccines against gastrointestinal nematode parasites, particularly Haemonchus contortus. Parasitol Today. 1999; 15: 116-22.

Pandeya SN, Sriram D, Nath G, Declercq E. Synthesis, antibacterial, antifungal and anti HIV activities of schiff and mannich bases derived from isatin derivatives and $\mathrm{N}-[4-$ (4'chlorophenyl)thiazol-2-yl] thiosemicarbazide. Eur J Pharm Sci. 1999; 9: 25-31.

Sarnim G, Sanjay ST, Roshan A, Vedamurthy AB, Joy HH. Artemisia indica extracts as anthelminthic agent against Pheretima posthuma. Int J Pharm Pharm Sci. 2013; 5 (Suppl 3): $259-62$.

Siddique M, Saeed AB, Dogar NA, Ahmad S. Biological potential of synthetic hydrazide based Schiff bases. J Sci Innov Res. 2013; 2: 651-57.

Sharma MC, Sahu NK, Kohli DV, Chaturvedi SC, Sharma S. Synthesis, characterization and biological activities of some 1 -(nicotinylamino-2-subs-tituted azetidine-4-ones as potential antibacterial agents. Dig J Nanomater Bios. 2009; 4: 361-67.

Suresh CH, Rao JV, Jayaveera KN, Subudhi HK. Synthesis and anthelminitc activity of 3(2-hydrazino benzothiazoles)-substituted indole-2-one. IJPR. 2011; 2: 257-61.

Tarafder MTH, Khan AR. Peroxo complexes of zirconium (IV), thorium (IV), molybdenum (VI), tungsten (VI) and uranium (VI) containing two quadridentate on to Schiff bases. Polyhedron 1991; 10: 819-22.

Valentina P, Ilango K, Deepthi M, Harusha P, Pavani G. Antioxidant activity of some substituted 1,2,4-triazo-5-thione Schiff base. J Pharm Sci Res. 2009; 1: 74-77.

Varshney MM, Husain, A, Parcha V. Synthesis, characterization and biological evaluations of 2-(4- hydroxyaryl)- $\mathrm{N}^{\prime}-\left(\left\{5^{\prime}-\right.\right.$ (substituted aryl)-furan-2'-yl\}-methylidene)-ketohydrazides Schiff bases. Der Pharma Chemica. 2014; 6: 241-47.

Venugopala KN, Jayashree BS. Synthesis of carboxamides of 2'-amino-4'-(6-bromo-3-coumarinyl) thiazole as analgesic and antiinflammatory agents. Ind J Het Chem. 2003; 12: 30710.

\footnotetext{
Author Info

Asif Husain (Principal contact)

e-mail: drasifhusain@yahoo.com; Phone: +91-11-26059681, 26059688, ext. 5647, Mobile- +91-989-1116086
} 